\title{
Effect of storage on recovery of cytomegalovirus from necropsy tissue
}

\author{
FRANCISCO F. MACASAET ${ }^{1}$, THOMAS F. SMITH, AND KEITH E. HOLLEY \\ From the Mayo Clinic and Mayo Foundation, Rochester, Minnesota, USA
}

SYNOPSIS Cytomegalovirus (CMV) was isolated from lung tissue in 8 of $55(14.6 \%)$ necropsies on patients who had received immunosuppressive therapy. Recovery of CMV was best (14 of 16 specimens, $87 \%$ ) from fresh tissue that had been processed immediately. Storage of specimens at $4^{\circ} \mathrm{C}$ before inoculation into cell cultures slightly reduced, to $58 \%$, the recovery of CMV. However, conventional freezing of tissue to $-20^{\circ} \mathrm{C}$ for four to seven days significantly reduced the recovery of $\mathrm{CMV}$, to $25 \%$ ( $\mathrm{P}<0.001)$. In three of eight specimens from which virus was recovered, CMV inclusion bodies were detected in both touch preparations and tissue sections of the lung. No inclusion bodies were found on tracheal smears. Sixty-five percent of the virus-negative group had measurable complement-fixing antibody in blood taken at necropsy, compared with $86 \%$ in the virus-positive group. However, there was no significant difference in antibody levels in the two groups. Our study indicates that specimens submitted for CMV isolation should be sent for virus isolation as rapidly as possible and should not be frozen. The level of antibody in a single serum taken at necropsy does not correlate well with morphological or cultural evidence of active infection.

Proof of cytomegalovirus (CMV) infection depends on the isolation and identification of the virus. However, the lability of this organism in stored specimens can preclude successful culture. In hospitals where virus isolation facilities are not available, tissue for CMV study is often stored before it can be sent to referral centres. The present report compares CMV recovery rates from (1) fresh, (2) refrigerated, and (3) frozen tissues, all removed at necropsy. These data are correlated with the frequency of CMV inclusion bodies and with antibody levels in necropsy blood specimens.

\section{Material and methods}

\section{STUDY POPULATION}

Patients were selected who had been immunosuppressed, either because of disease or because of treatment. There were 55 necropsy cases in all- 45 patients with leukaemia-lymphoma, five with collagen diseases, two with renal transplants, two with undefined myeloproliferative disorders, and one with

'Present address: Cleveland Metropolitan General Hospital, Department of Pathology, Cleveland, Ohio 44109, USA.

Address reprint requests c/o Section of Publications, Mayo Clinic, 200 First Street SW, Rochester, MN 55901, USA.

Received for publication 25 April 1976 pancreatic carcinoma. Their ages ranged from 6 to 88 (mean 52) years; 33 were males and 22 were females.

\section{COLLECTION OF TISSUE}

At necropsy the thoracic organs were removed en bloc. Lung tissue samples (about 4 by 4 by $4 \mathrm{~cm}$ ) were obtained aseptically in areas with gross pathology (if present) and also from the opposite side where there were no macroscopic lesions. In cases where no gross evidence of pneumonia was present, samples were obtained at random (from both sides of the lung). Liver tissue was similarly sampled for virus culture and histological study.

\section{PROCESSING OF TISSUE}

From the necropsy room specimens were transported on ice to the virus laboratory immediately, and tissues were cut into six pieces-one for immediate processing by the virus laboratory, one for the general microbiology tissue laboratory for routine bacterial, fungal, and viral cultures, two for storage at $4^{\circ} \mathrm{C}$ to be processed one day and four to seven days later, one for freezing at $-20^{\circ} \mathrm{C}$ to be processed four to seven days later, and the last piece for touch preparation and histological study. The specimens processed by the tissue laboratory were then transported to the virus laboratory within 
24 hours. The preparation of 10 to $20 \%$ tissue homogenate in heart infusion broth with antibiotics has been described (Armstrong et al, 1971).

We considered as zero-time in the present study when the specimen arrived in the virus laboratory. In a previous study, we compared the time intervals from death to necropsy and from necropsy to culture for lung specimens yielding CMV and from those that were virus-negative. The total times from death to culture for the two groups were not significantly different (Smith et al, 1975).

\section{TOUCH PREPARATION}

Tracheal and tissue impression smears were fixed in $95 \%$ ethyl alcohol and stained with haematoxylin and eosin.

\section{VIRUS CULTURE}

The procedure for inoculation and identification of viral isolates has also been described (Smith et al, 1975). Briefly, the supernatant fractions (10 to $20 \%$ tissue extract) were inoculated into WI-38 cells $(0.25 \mathrm{ml}), \mathrm{HeLa}$ cells $(0.3 \mathrm{ml})$, and primary rhesus monkey kidney tissue $(0 \cdot 3 \mathrm{ml})$. Cultures were observed for cytopathic effects characteristic for CMV for 14 days; if none developed, the WI-38 cells were treated with trypsin-ethylenediaminetetraacetate solution for transfer to fresh cultures. These blind passages were further observed for four to six weeks.

\section{COMPLEMENT-FIXATION TEST}

The complement-fixation antigens (AD-169 strain of CMV) were procured from a commercial source (Flow Laboratories); a standard microtitre technique was used (Sever, 1962).

\section{Results}

Viruses were isolated from $12(22 \%)$ of 55 cases studied; eight of these were CMV, three were myxoviruses, and one was a herpes simplex virus. The frequency of isolation for CMV alone was $14.6 \%$. CMV was recovered from both lungs in all except one case (case 5, table I). Herpes simplex virus and two of three haemadsorbing virus isolates were also isolated from specimens from both sides of the lungs.

CMV was isolated from 14 of $16(87 \%)$ fresh lung specimens processed immediately after necropsy. However, after one day at $4^{\circ} \mathrm{C}$, virus was recovered from only seven of $12(58 \%)$ available specimens; this decline in frequency of isolation is not statistically significant. The isolation frequency from tissues stored for four to seven days at $4^{\circ} \mathrm{C}(58 \%)$ was similar to that from tissue refrigerated for just one day. Interestingly, CMV was not detected from the left lung in case 8 after storage for one day but was recovered after four to seven days at $4^{\circ} \mathrm{C}$. Freezing of specimens $\left(-20^{\circ} \mathrm{C}\right)$ for four to seven days significantly reduced the CMV recovery, to $25 \%$ $(P<0.001)$. One case (case 4) was unique in that CMV was not isolated from fresh tissue but was recovered from lung tissue that had been stored at $4^{\circ} \mathrm{C}$ and at $-20^{\circ} \mathrm{C}$ and processed four to seven days after the necropsy.

Aliquots of the original $10 \%$ tissue extracts (pre@ pared after storage for different times at differen temperatures) and used in the initial isolation studie were kept frozen at $-20^{\circ} \mathrm{C}$ for up to four months. To demonstrate further the effect of freezing on virus isolation, 25 specimens that initially yielded CMV were inoculated again into WI-38 culture. There was a significant reduction in the frequency of reisolation, as CMV was recovered from only three $(12 \%)(\mathrm{P}<0.001)$. These recovery data are summarized in table II.

Touch preparations of lung tissue revealed CMV inclusion bodies in three of eight cases that were positive for virus by culture (table I) (figure). Tissue

\begin{tabular}{|c|c|c|c|c|c|c|c|c|c|c|c|c|c|c|c|c|c|c|}
\hline \multirow[t]{3}{*}{ Case } & \multirow{3}{*}{$\begin{array}{l}\text { Clinical } \\
\text { diagnosis }\end{array}$} & \multirow{3}{*}{$\begin{array}{l}\text { Age } \\
(y r)\end{array}$} & \multirow[t]{3}{*}{$\operatorname{Sex}$} & \multicolumn{9}{|c|}{ Virus recovery } & \multicolumn{5}{|c|}{ Inclusion body detection } & \multirow{3}{*}{$\begin{array}{l}C M V- \\
C F \\
\text { titre }\end{array}$} \\
\hline & & & & \multicolumn{4}{|c|}{ Left lung } & \multicolumn{4}{|c|}{ Right lung } & \multirow[t]{2}{*}{ Liver } & \multicolumn{3}{|c|}{ Touch preparation } & \multicolumn{2}{|c|}{ Tissue section } & \\
\hline & & & & $V L$ & $A$ & $\boldsymbol{B}$ & $C$ & $V L$ & $A$ & $\boldsymbol{B}$ & $C$ & & Trachea & L lung & R lung & $\begin{array}{l}R \text { or } L \\
\text { lung }\end{array}$ & Liver & \\
\hline 1 & Leukaemia & 24 & $\mathbf{M}$ & + & ND & ND & ND & + & - & - & - & - & - & + & ND & + & - & $1: 2$ \\
\hline 2 & Leukaemia & 78 & $\mathbf{M}$ & + & + & + & - & + & ND & ND & ND & - & - & ND & - & - & - & $1: 32$ \\
\hline 3 & Lymphoma & 71 & $\mathbf{F}$ & + & ND & ND & ND & + & + & + & + & - & - & + & - & + & - & $1: 32$ \\
\hline 4 & Lymphoma & 59 & $\mathbf{M}$ & - & - & + & + & + & ND & ND & ND & - & - & - & - & - & - & $1: 4$ \\
\hline 5 & Lymphoma & 64 & $\mathbf{F}$ & - & - & - & - & + & + & + & - & - & - & - & - & - & - & Antic \\
\hline \multirow{2}{*}{$\begin{array}{l}6 \\
7\end{array}$} & Leukaemia & 58 & $\mathbf{F}$ & + & + & + & - & + & + & - & - & - & ND & - & - & - & - & $1: 32$ \\
\hline & $\begin{array}{l}\text { Systemic lupus } \\
\text { erythematosus }\end{array}$ & 52 & $\mathbf{F}$ & + & $t$ & + & - & + & + & - & & & ND & - & - & & & $1: 8$ \\
\hline 8 & Lymphoma & 73 & $\mathbf{M}$ & + & - & + & - & + & - & $\overline{-}$ & - & - & - & $\overline{+}$ & $\bar{t}$ & $\bar{t}$ & $\overline{+}$ & $1: 16$ \\
\hline
\end{tabular}

Table I Comparative rate of CMV recovery from necropsy tissues and incidence of finding CMV inclusion bodies by histopathology

$\mathrm{VL}=$ fresh tissue processed by virus laboratory; $\mathrm{A}$ and $\mathrm{B}=$ tissues stored at $4^{\circ} \mathrm{C}$ for one day and four to seven days, respectively; $\mathrm{C}=$ tissue frozen at $-20 \mathrm{C}$ for four to seven days; $\mathrm{ND}=$ not done; $+=$ positive; $-=$ negative; Antic $=$ anticomplementary. 
sections from the same three cases showed characteristic inclusion bodies. No correlation between the presence of inclusions and a pneumonic process was observed. One liver specimen showed inclusion bodies but was negative by culture. Tracheal smears in all 55 cases studied did not show morphological evidence of CMV infection.

\begin{tabular}{|c|c|c|c|c|}
\hline Storage conditions & $\begin{array}{l}\text { Total no. } \\
\text { tested }\end{array}$ & $\begin{array}{l}\text { No. } \\
\text { positive }\end{array}$ & $\begin{array}{l}\text { No. } \\
\text { negative }\end{array}$ & $\begin{array}{l}\% \\
\text { positive }\end{array}$ \\
\hline \multirow{5}{*}{$\begin{array}{l}\text { Fresh tissue } \\
\text { Stored } 1 \text { day, } 4^{\circ} \mathrm{C} \\
\text { Stored } 4-7 \text { days, } 4^{\circ} \mathrm{C} \\
\text { Stored frozen, }-20^{\circ} \mathrm{C} \text {, } \\
4-7 \text { days } \\
10 \% \text { Tissue extracts } \\
\text { stored at }-20^{\circ} \mathrm{C} \text { up } \\
\text { to } 4 \mathrm{mth}\end{array}$} & 16 & 14 & 2 & $87^{1}$ \\
\hline & $12^{2}$ & 7 & 5 & 58 \\
\hline & 12 & 7 & 5 & 58 \\
\hline & 12 & 3 & 9 & 25 \\
\hline & 25 & 3 & 22 & 12 \\
\hline
\end{tabular}

Table II Recovery of CMV from fresh and stored tissues

${ }^{1}$ Decline of recovery from $87 \%$ to $25 \%$ and $12 \%$ after storage is statistically significant $(P<0.001)$.

2Storage protocol in $\mathbf{4}$ of 16 specimens was not completed and therefore these were excluded from further analysis (marked 'not done' in table I).

${ }^{3}$ Original $10 \%$ tissue extracts (from both fresh and stored tissues) used in initial virus isolation procedure and found to contain CMV.

CMV complement-fixing (CF) antibodies were measured in 43 virus-negative and seven viruspositive cases (one serum with anticomplementary activity was excluded). Of the former group, 28 $(65 \%)$ displayed $\mathrm{CF}$ titres in the lange of $1: 4$ to $1: 128$ (mean $1: 25)$, whereas, of the latter, six $(86 \%)$ showed titres that ranged from 1:4 to $1: 32$ (mean $1: 20)$.

\section{Discussion}

The lability of CMV under storage conditions has been the subject of numerous reports; however, those studies were done under highly experimental conditions. For example, in the study of Vonka and Benyesh-Melnick (1966), the stability of CMV depended upon a combination of variables such as the type of buffer used as diluent, the inactivation temperature, and the presence of serum. Similarly, Feldman (1968) demonstrated greater inactivation of CMV in urine with added sorbitol at $4^{\circ} \mathrm{C}$ or $-60^{\circ} \mathrm{C}$ compared with $-20^{\circ} \mathrm{C}$. However, CMV was inactivated more quickly at $-20^{\circ} \mathrm{C}$ than at $4^{\circ} \mathrm{C}$ or $-60^{\circ} \mathrm{C}$ without sorbitol, and all measurable infectivity was lost in two weeks of storage. Conversely, the persistence of inoculated CMV into whole blood (under blood-banking conditions) for 28 days and in fresh frozen plasma for 97 days has been reported by Armstrong et al (1971). Hildebrant et al (1968) preserved CMV activity by quick-freezing and storage in liquid nitrogen, but this may not be readily available in many laboratories.

Our study is different from others in that the storage conditions we employed are those that are available in most laboratories, and most previous investigations on the isolation of CMV from tissues did not examine the effect of storage on virus recovery. Our data show a much higher yield of CMV from fresh tissue $(87 \%)$ as compared with frozen tissue $(25 \%)(\mathrm{P}<0.001)$. Although virus recovery from tissue stored at $4^{\circ} \mathrm{C}$ for several days similarly declined (from 87 to $58 \%$ ), this reduction is not significant. In tissue extracts frozen for up to four

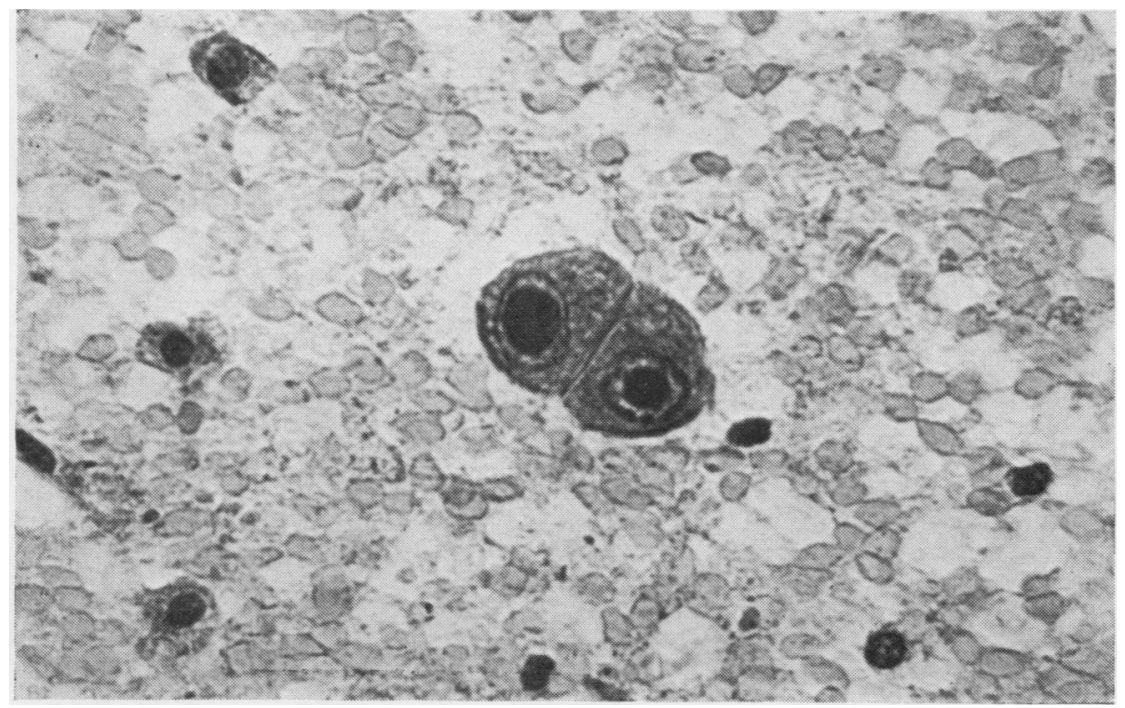

Figure Touch preparation of lung. Note characteristic intranuclear inclusion within two enlarged cells. (Haematoxylin and eosin $\times$ 43.) 
months, marked virus inactivation occurred. Nonuniform distribution of virus probably explains the disparity of CMV recovery from several cases. We conclude that tissues intended for CMV isolation study, especially if they will be transported to other laboratories, should be kept at refrigeration temperature instead of frozen, and for as short a time as possible.

The detection of CMV inclusion bodies in just one-third of infected tissues confirms our earlier report (Macasaet et al, 1975) that virus isolation is a sensitive method of establishing the presence of CMV infection. The tissue impression smear is a rapid and accurate method of demonstrating CMV inclusions. Our failure to detect inclusion bodies in the tracheal swabs may have been due to localization of infection in the lung parenchyma.

The serological results differ from our previous data (Smith et al, 1975), in which CMV was isolated about seven times more often from individuals with a CF titre of 1:16 or greate1. In the present study the virus-negative group showed a slightly higher antibody level (mean 1:25) than did the virus-positive group (mean $1: 20$ ). However, only $65 \%$ of the virusnegative group had a measurable CF titre compared with $86 \%$ of the virus-positive group. Since the population in the present study was specially selected, it is possible that those with high CF titres were in- fected but that we failed to isolate the virus. In immunosuppressed patients who have disseminated CMV infection. there may be a terminal drop in $\overrightarrow{\stackrel{\vec{s}}{\vec{f}}}$ antibody titre (Craighead, 1969).

We wish to thank Louise Reichrath for her excel- $\frac{\overline{\bar{D}}}{\sqrt{5}}$ lent technical assistance.

\section{References}

Armstrong, D., Ely, M., and Steger, L. (1971). Post-transfusion cytomegaloviremia and persistence of cytomegalo $\vec{\omega}$ virus in blood. Infect. Immun., 3, 159-163.

Craighead, J. E. (1969). Immunologic response to cyto megalovirus infection in renal allograft recipients. Amer. J0 Epidem., 90, 506-513.

Feldman, R. A. (1968). Cytomegaloviruses in stored urine specimens: a quantitative study. J. Pediat., 73, 611-614. N

Hildebrant, R. J., Sever, J. L., and Anderson, B. (1968). Preservation of infectious cytomegalovirus. Proc. Soc. exp. Biol (N.Y.), 129, 504-506.

Macasaet, F. F., Holley, K. E., Smith, T. F., and Keys, T. F음 (1975). Cytomegalovirus studies of autopsy tissue. II Incidence of inclusion bodies and related pathologic data Amer. J. clin. Path., 63, 859-865.

Sever, J. L. (1962). Application of a microtechnique to viraf serological investigations. J. Immunol., 88, 320-329.

Smith, T. F., Holley, K. E., Keys, T. F., and Macasaet. F. F (1975). Cytomegalovirus studies of autopsy tissue. I. Virus isolation. Amer. J. clin. Path., 63, 854-858.

Vonka, V. and Benyesh-Melnick, M. (1966). Therrofo-inactivation of human cytomegalovirus. J. Bact., 91, 221. 226. 